\title{
Water and Waste Water Tariffs for New Residential Construction in California
}

\author{
D.C. Fisher and J.D. Lutz \\ Environmental Energy Technologies Division \\ Lawrence Berkeley National Laboratory \\ University of California \\ Berkeley, California 94720 \\ U.S.A.
}

April 2006 
$-2-$ 


\section{Water and Waste Water Tariffs for New Residential Construction in California}

\section{Introduction}

Title 24 contains guidelines requiring a certain level of energy efficiency in new residential construction in California. These guidelines may be changed to include measures that save energy by reducing hot water consumption of water using appliances and fixtures. Some changes may also reduce the amount of waste water released to the sewer. In order to calculate the full value of such reductions to the consumer, it is necessary to determine and include the marginal cost of the water saved.

\section{Sample Selection and Data Collection}

In order to do this, we collected water and waste water tariffs in California cities and counties where there is a high level of new residential construction. We determined the areas for which we would gather data by first obtaining data from the Construction Industry Research Board, an institution which compiles construction related statistics within California. We purchased a data set which listed the number of new single family homes and units of multi-family housing built in each California city plus the unincorporated areas of each county in the year 2004. We summed the number of single family homes and number of units of multifamily homes, and then ordered the data from highest to lowest number. We then began to gather data on residential water and waste water tariffs for the top 100 cities and county unincorporated areas on this list. The list included 79 cities and the unincorporated areas of 21 counties.

For each city or county, we first looked at that location's website - all 100 of the cities and counties on our list have an official website. We then looked for current water and waste water tariffs on these websites. We found that residential water tariff information was available online for 64 cities and 1 county (El Dorado) and that waste water information was available for 54 cities and 1 county (El Dorado). However, for approximately half of these locations, it was necessary to contact someone for clarification or further information. For example, some cities only listed the tariff information for single family homes on their websites, and it was necessary to contact city staff for information on tariffs for multi-family residences.

For each city or county in our top 100 which did not have its tariff information on its website, we tried to identify a contact person or office, and then emailed or telephoned for more information. If the city had a "utilities" department, that is generally who we contacted. Otherwise, we would contact their "billing" or "finance" department. In the case of the counties, we generally contacted their planning or land development division, and asked the contact to identify the names of the two or three largest residential water and waste water service providers in unincorporated areas of the county. Once these were identified, we went to the provider's website to look for tariff information, and contacted them directly by email or phone if such information was not on their website. 
This process has proven to be quite labor intensive. To date we entered data into our database on residential water tariffs for 74 cities or counties, and on residential waste water tariffs for 65 cities or counties. The cities and counties for which we have water tariffs account for $64 \%$ of all new housing units built in 2004 , and for waste water tariffs we have $57 \%$ coverage. Table 1 lists all of the utilities for which data was entered. The rest of this report describes what we found for those localities. We also describe the structure of the database, and some of the assumptions made when entering data.

\section{Table 1. Utilities Entered into Water TAP Database} Name of Utility

Apple Valley Ranchos Water Company

Beaumont-Cherry Valley Water District

Calaveras County Water District

California Water Service Company

Carlsbad Municipal Water District

City of American Canyon, Water Department

City of Bakersfield, Public Works Department, Wastewater Division

City of Beaumont

City of Brentwood

City of Ceres

City of Chino

City of Chula Vista, Public Works Department

City of Clovis, Public Utilities

City of Folsom

City of Fresno, Public Utilities Department

City of Hayward

City of Lincoln

City of Livermore

City of Loma Linda, Water/Sewer

City of Los Angeles, Bureau of Sanitation

City of Los Banos

City of Merced

City of Oceanside

City of Orange

City of Oxnard Water Division

Utility Type*

DW

DW

B

DW

B

$\mathrm{B}$

WW

WW

B

B

B

WW

$\mathrm{B}$

B

B

B

WW

$\mathrm{B}$

B

WW

B

B

B

DW

DW

B

B

B

B

WW

DW

WW

WW

DW

B

B

City of Stockton, Municipal Utilities Department

$* \mathbf{D W}=$ water, $\mathbf{W W}=$ waste water, $\mathbf{B}=\mathbf{B o t h}$ 


$\begin{array}{ll}\text { Table 1. (continued) Utilities Entered into Water TAP Database } \\ \text { Name of Utility } & \text { Utility Type* } \\ \text { City of Tracy } & \text { B } \\ \text { City of Turlock } & \text { B } \\ \text { City of Vallejo, Water Department } & \text { DW } \\ \text { City of Yuba City } & \text { B } \\ \text { Coachella Valley Water District } & \text { B } \\ \text { Contra Costa Central Sanitary District } & \text { WW } \\ \text { Corona, Department of Water and Power } & \text { B } \\ \text { Crestline Sanitation District } & \text { WW } \\ \text { Cucamonga Valley Water District } & \text { B } \\ \text { Dublin San Ramon Services District } & \text { B } \\ \text { East Bay Municipal Utility District } & \text { B } \\ \text { Eastern Municipal Water District } & \text { B } \\ \text { El Dorado Irrigation District } & \text { B } \\ \text { Elsinore Valley Municipal Water District } & \text { B } \\ \text { Fairfield Municipal Utilities } & \text { DW } \\ \text { Fontana Water Company } & \text { DW } \\ \text { Hesperia Water District } & \text { B } \\ \text { Indio Water Authority } & \text { DW } \\ \text { Inland Empire Utilties Agency } & \text { WW } \\ \text { Irvine Ranch Water District } & \text { B } \\ \text { Los Angeles County Sanitation Districts } & \text { WW } \\ \text { Los Angeles County Waterworks Districts } & \text { DW } \\ \text { Los Angeles Department of Water and Power } & \text { DW } \\ \text { Mission Springs Water District } & \text { B } \\ \text { Newhall County Water District } & \text { DW } \\ \text { Otay Water District } & \text { DW } \\ \text { Paso Robles Wastewater Division } & \text { B } \\ \text { Pinon Hills Water District } & \text { DW } \\ \text { Placer County Water Agency } & \text { DW } \\ \text { Redding Municipal Utilities Department } & \text { B } \\ \text { Sacramento County Sanitation District 1 } & \text { WW } \\ \text { Sacramento County Water Agency } & \text { DW } \\ \text { San Clemente, Water \& Sewer } & \text { B } \\ \text { San Francisco, Public Utilities Commission } & \text { B } \\ \text { San Jose Municipal Water } & \text { DW } \\ \text { Sweetwater Authority } & \text { DW } \\ \text { Vallecitos Water District } & \text { B } \\ \text { Victor Valley Water District } & \text { DW } \\ \text { West Sacramento Public Works } & \\ \text { * DW = water, WW = waste water, B Both } & \\ & \end{array}$

\section{Structure of Tariffs}

Although there is a great deal of variation in tariff structures, there are also some features which are common to most. Most tariffs include a fixed monthly cost that is independent 
of the quantity of water consumed, or waste water released. The fixed monthly cost is usually based on the water meter size in inches; the larger the meter size, the larger the fixed monthly cost. Sometimes the fixed monthly cost is based on other factors, such as lot size or climate zone.

In addition, nearly all water tariffs include a quantity charge for the amount of water consumed. This quantity is usually measured in units of hundred cubic feet, or HCF. One HCF equals 748 gallons. A few utilities charge in units of thousands of gallons instead.

The most common water tariff structure we found was a fixed monthly cost based on meter size, plus a single rate for the quantity charge. Nearly half $(45 \%)$ of the tariffs in our database have this structure.

Most of the rest of water utilities have quantity charges that are tiered. For example, a utility may charge $\$ 1.25$ per HCF for the first 10 HCF per month, $\$ 1.50$ for the next 10 $\mathrm{HCF}$, and $\$ 2$ for each additional HCF after that. Nearly all utilities that have tiered rates have ascending rates, i.e. where the charge per HCF goes up as usage goes up. This rate structure helps to encourage water conservation.

A few utilities base the cutoff points between tiers on factors such as climate zone or lot size. There was one utility in our sample, Irvine Ranch Water District, which bases the cutoff point between tiers on a complex formula that includes number of residents, lot size (for single family and townhomes), and an evapotranspiration index as recorded by three local weather stations (residences are divided into three climate zones and the data from one of the three stations is applied).

Some utilities also add a surcharge on its quantity rate for residences located at high elevations, to recover the additional cost of pumping water uphill.

Most waste water tariffs (74\%) include a fixed monthly cost only. Those that include a quantity charge base it on metered water consumption and then apply a formula to estimate what fraction of this water is released to the sewer. This is discussed in more detail in the results section below.

\section{Structure of Database}

The database contains 4 tables. The utility table contains basic information about the water and waste water utilities, including name, type of utility (water, waste water or both), dates of summer and winter season (if any), etc. The Utility_Cities table contains information about which cities are covered by a given utility. The tariff table contains basic data on each tariff of each utility, indicating who is covered by the tariff based on meter size and other parameters, and also giving effective dates of the tariff when available. The component table, which will be described in more detail below, breaks each tariff down into components, each of which has one unique rate associated with it. 
Tables A-1 through A-4 in the Appendix list each field in each table, along with a brief description of what the field contains.

Water and wastewater tariff documents typically contain the rates charged for several different classes of customers. When entering tariffs into the database, each "tariff" in our database consisted of all the charges that a particular class of customer might see. This meant, for example, that if there was a different fixed monthly cost depending on the customer's meter size, a separate tariff was entered for each meter size. Thus, one tariff document might yield a dozen separate tariffs in our database, one for each meter size. If there were different climate zones, the charges in each climate zone would comprise a separate tariff. .

Each tariff was further broken down into "components", and this information was stored in the "components" table. For any given tariff, each component has one unique rate associated with it. So, for example, a tariff which consists of a fixed monthly charge of $\$ 15 /$ month, and water consumption charges in three tiers, of say, $\$ 1.00$ per HCF (hundred cubic feet, or 748 gallons) for the first $5 \mathrm{HCF}$, and $\$ 1.50$ per $\mathrm{HCF}$ for the next $5 \mathrm{HCF}$, and $\$ 2.00$ per HCF for all additional HCF, would have 4 components in our components table - one for the fixed charge, and one each for each of the three tiers. There is also a "group" field, and "sequence" field, to indicate which charges go together and in what sequence. In the example given here, the fixed monthly cost would be a group with one element, and the three tiers would be a second group containing a total of three elements.

\section{Results}

Our database currently includes tariff information for 41 providers of both water and waste water services, 21 providers of water services only, and 13 providers of waste water services only. Adding these together, we have a total thus far of 75 companies or governmental agencies, of which 62 provide water service and 54 provide waste water service.

Nearly all of the water tariffs in our sample also include a quantity charge based on metered water consumption. In California, it has been a requirement since 1992 that all new construction include a water meter. Since that law went into effect, most water providers have chosen to base tariffs on water consumption, but a few have not. In our sample, we found that only 4 out of 62 water service providers $(6 \%)$ have flat rates for new residences. The largest of these is the City of Sacramento, which is on record as opposing metered water rates.

For those tariffs which have rates based on water consumption, we determined what the marginal rate would be for the $11^{\text {th }} \mathrm{HCF}$ consumed in a month $(10 \mathrm{HCF}$ per month is a typical quantity for residential water consumption). Since each utility might have several tariffs based on meter size, but with the same marginal rate, for each utility we identified the unique marginal rates. For 4 utilities, the value was $\$ 0$, because even though those utilities do have a water consumption charge, there is a certain amount of water usage

that is included in the monthly fixed fee, and the $11^{\text {th }} \mathrm{HCF}$ fell below this amount. Of the 
non-zero values, the lowest was $\$ 0.24 / \mathrm{HCF}$, and the highest was $\$ 5.28 / \mathrm{HCF}$. This high value was for a utility which has what we refer to as a "disappearing" block structure, i.e. the lower rate for the first 0 to $10 \mathrm{HCF}$ is lost if an $11^{\text {th }} \mathrm{HCF}$ is consumed, so the effective rate for the $11^{\text {th }} \mathrm{HCF}$ is the rate for that HCF plus the additional charge that is incurred on HCF 0 to 10 . The unweighted average value for the $11^{\text {th }} \mathrm{HCF}$, including the zeroes for flat rate tariffs, was $\$ 1.40$. The average of the non-zero values was $\$ 1.52 / \mathrm{HCF}$. Figure 1 shows the distribution of charges for the unique tariffs.

\section{Number of Unique Tariffs with a Given Marginal Rate (\$/HCF)}

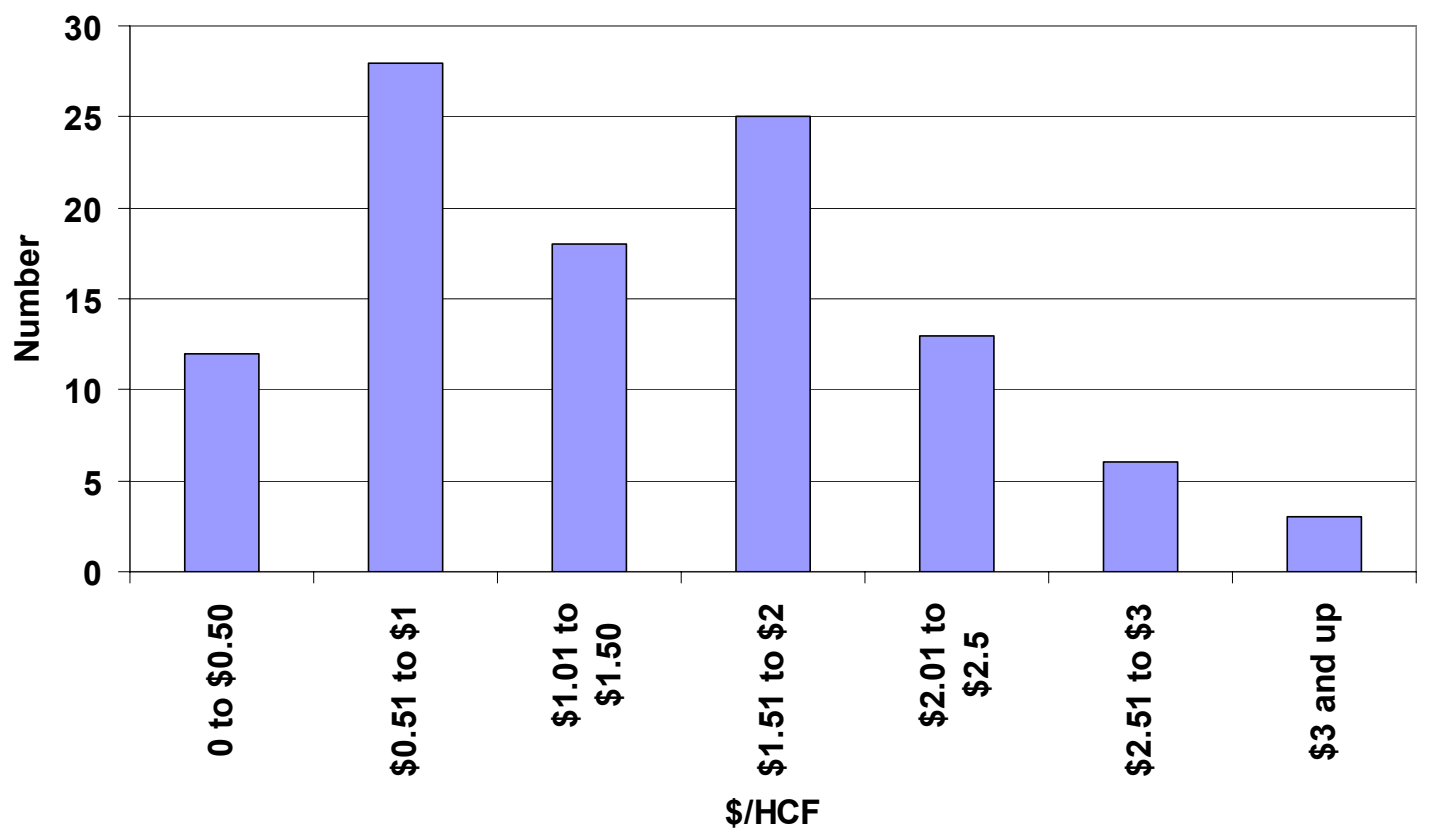

Figure 1. Distribution of Marginal Rates for Water Consumption $\left(11^{\text {th }} \mathrm{HCF}\right.$ in a month)

For waste water, we found that 41 out of 54 service providers ( $76 \%$ of our sample) have flat rates that are completely independent of water consumption. Of the remaining 13 there are 6 who base their rates on metered water consumption during a base period in the previous winter - the rates are fixed for a year based on the last year's water consumption and then adjusted once a year. The remaining 7 base their rates on each month's metered water consumption. Sometimes the utilities apply an additional multiplier to estimate what fraction of water use (whether it's winter water use or monthly metered water) is released to the sewer (typically $75 \%$ to $90 \%$ ). For those utilities that apply such a multiplier, we multiplied the nominal rate per HCF times this multiplier to calculate the actual charge per metered HCF, and entered the actual charge into our database. For example, if a utility has a nominal sewer charge of $\$ 2.00 / \mathrm{HCF}$, and multiplies $90 \%$ times metered water use to estimate sewer use, we multiplied $\$ 2.00$ times $90 \%$ and entered $\$ 1.80 / \mathrm{HCF}$ into our database, since this is the effective charge per HCF of metered water use. 
Of the 13 companies that base sewer rates on water use, there were 2 that only based it loosely on water consumption within broad categories. For example, a city might charge $\$ 10 /$ month for users whose estimated sewer use is 0 to $5 \mathrm{HCF}, \$ 15 /$ month for 6 to 10 $\mathrm{HCF}$, and $\$ 20 /$ month for 11 or more HCF. We modeled this in the database by counting the $\$ 10$ charge for the lowest usage category as a fixed monthly cost (since all users pay at least this amount). We entered consumption charges of \$ $0 / \mathrm{HCF}$ for the first $5 \mathrm{HCF}$, $\$ 5 / \mathrm{HCF}$ for the $6^{\text {th }} \mathrm{HCF}$ (this is the additional cost incurred by the $6^{\text {th }} \mathrm{HCF}$ since it bumps the user up into the next category), $\$ 0$ for the $7^{\text {th }}$ through $10^{\text {th }} \mathrm{HCF}, \$ 5$ for the $11^{\text {th }} \mathrm{HCF}$, and $\$ 0$ for all additional HCF.

There were 17 unique tariffs for the 13 companies which have consumption charges (4 companies had different rates for multifamily residences than for single family). We calculated the charge for the $11^{\text {th }} \mathrm{HCF}$ consumed in a month. There were 4 tariffs out of 17 where the marginal rate was $\$ 0$. The lowest non-zero value was $\$ 0.47 / \mathrm{HCF}$, the highest was $\$ 11.54 / \mathrm{HCF}$. The highest value was from one of the two that bases its rates on categories of consumption, as described above. The $11^{\text {th }} \mathrm{HCF}$ is the transition from one category to the next highest, thus the marginal cost for that one HCF is quite high.

The average marginal cost per HCF of waste water, including zeroes for all 41 of the flat rate utilities, was $\$ 0.74 / \mathrm{HCF}$. The average of the non-zero values was $\$ 3.23 / \mathrm{HCF}$. 


\section{Appendix}

This appendix lists all of the fields in each of the four Water TAP database tables. There is a brief description of each field, and the types of values it contains.

Table A-1. Fields in the Utility Table of the Water TAP Database

\begin{tabular}{|c|c|c|c|}
\hline Field Name & Data Type & Field Values & Description and Notes \\
\hline util id & AutoNumber & $\begin{array}{l}\text { Positive } \\
\text { integers }\end{array}$ & The unique identifier for each utility. \\
\hline Epa_id & Text(20) & & $\begin{array}{l}\text { Reserved for entry of EPA Safe Drinking } \\
\text { Water Act ID of the utlity - not currently } \\
\text { populated }\end{array}$ \\
\hline Util_type & Text(2) & $\begin{array}{l}\text { DW, WW or } \\
\text { B }\end{array}$ & $\begin{array}{l}\text { DW = provider of water only, WW = provider } \\
\text { of waste water services only, } \mathrm{B}=\text { provides } \\
\text { both }\end{array}$ \\
\hline Name & Text(200) & Text & Common name of the utility \\
\hline state id & text(2) & Two letters & $\begin{array}{l}\text { Two letter abbreviation for state in which } \\
\text { utility is located (CA for this project) }\end{array}$ \\
\hline Pop_served & Long Integer & $\begin{array}{l}\text { Positive } \\
\text { integers }\end{array}$ & $\begin{array}{l}\text { The number of people served by the utility. } \\
\text { Entered when available. }\end{array}$ \\
\hline Conn_served & Long Integer & $\begin{array}{l}\text { Positive } \\
\text { Integers }\end{array}$ & $\begin{array}{l}\text { The number of service connections. } \\
\text { Entered when available. }\end{array}$ \\
\hline date_entered & Date/Time & dates & Date when utility entered into database \\
\hline date_expired & Date/Time & dates & $\begin{array}{l}\text { When applicable, "date_expired" is the date } \\
\text { when utility data found to be out of date. } \\
\text { This can occur when a utility merges with } \\
\text { another utility (not populated, available for } \\
\text { future use) }\end{array}$ \\
\hline last_update & Date/Time & dates & $\begin{array}{l}\text { Last time information was updated and/or } \\
\text { verified for this utility. }\end{array}$ \\
\hline ownership & $\operatorname{Text}(50)$ & $\begin{array}{l}\text { Municipal, } \\
\text { County, } \\
\text { Private }\end{array}$ & $\begin{array}{l}\text { Ownership of the utility. Entered when } \\
\text { available. }\end{array}$ \\
\hline $\begin{array}{c}\text { website } \\
\text { Website_tariff }\end{array}$ & $\begin{array}{l}\text { Text(100) } \\
\text { Text(255) }\end{array}$ & $\begin{array}{l}\text { text } \\
\text { Text }\end{array}$ & $\begin{array}{l}\text { Main web page address for the utility } \\
\text { Web page on which tariff data was found }\end{array}$ \\
\hline $\begin{array}{l}\text { Month_summer_be } \\
\text { gins } \\
\text { Day_summer_begi }\end{array}$ & Integer & 1 through 12 & $\begin{array}{l}\text { For utilities with seasonal rates, the month } \\
\text { in which the summer season begins }\end{array}$ \\
\hline $\begin{array}{l}\text { ns } \\
\text { Month summer en }\end{array}$ & Integer & 1 through 31 & Day on which the summer season begins \\
\hline ds & Integer & 1 through 12 & Month in which the summer season ends \\
\hline $\begin{array}{l}\text { Day_summer_ends } \\
\text { Comments }\end{array}$ & $\begin{array}{l}\text { Integer } \\
\text { Text(255) }\end{array}$ & $\begin{array}{c}1 \text { through } 31 \\
\text { Text }\end{array}$ & $\begin{array}{l}\text { Day on which summer season ends } \\
\text { Comments or notes from person who } \\
\text { entered the data. }\end{array}$ \\
\hline
\end{tabular}


Table A-2. Fields in the Tariff Table of the Water TAP Database

\begin{tabular}{|c|c|c|c|}
\hline Field Name & Data Type & Field Values & Description and Notes \\
\hline Tariff_id & AutoNumber & Whole numbers & Unique identifier for each tariff \\
\hline Tariff_type & $\operatorname{Text}(2)$ & DW or WW & $\mathrm{DW}=$ water tariff, $\mathrm{WW}=$ waste water \\
\hline Schedule & $\operatorname{Text}(100)$ & Text & $\begin{array}{l}\text { Utility specified "common" name for the } \\
\text { tariff }\end{array}$ \\
\hline Schedule_code & $\operatorname{Text}(50)$ & Text & $\begin{array}{l}\text { Official utility document designation (if any) } \\
\text { for this tariff (e.g. WA-1) }\end{array}$ \\
\hline Util_id & Long Integer & Whole number & Utility identifier for this tariff \\
\hline State & $\operatorname{Text}(2)$ & $\begin{array}{l}2 \text { letter state } \\
\text { code }\end{array}$ & State in which tariff is offered \\
\hline Market & $\operatorname{Text}(1)$ & $\mathrm{R}, \mathrm{C}, \mathrm{A}$ or $\mathrm{G}$ & $\begin{array}{l}\mathrm{R}=\text { residential, } \mathrm{C}=\text { commercial, } \mathrm{A}= \\
\text { agricultural, } \mathrm{G}=\text { general }\end{array}$ \\
\hline Submarket & $\operatorname{Text}(10)$ & SFR or MFR & $\begin{array}{l}\mathrm{SFR}=\text { single family residence, } \mathrm{MFR}=\text { multi- } \\
\text { family building }\end{array}$ \\
\hline Geog_area & $\operatorname{Text}(100)$ & Text & $\begin{array}{l}\text { geographic area covered by this tariff. If } \\
\text { blank, geographic area is equal to entire } \\
\text { service territory of the utility. }\end{array}$ \\
\hline Billing_period & $\operatorname{Text}(2)$ & $\mathrm{D}, \mathrm{M}, \mathrm{B}, \mathrm{Q}$ or $\mathrm{A}$ & $\begin{array}{l}\mathrm{D}=\text { daily (although customers are not billed } \\
\text { daily, this code is used when tariffs list rates } \\
\text { on a per day basis) } \mathrm{M}=\text { Monthly, } \mathrm{B}= \\
\text { bimonthly, } \mathrm{Q}=\text { quarterly, } \mathrm{S}=\text { semi-annually, } \\
\mathrm{A}=\text { Annually }\end{array}$ \\
\hline Metersize & $\operatorname{Text}(10)$ & Text & $\begin{array}{l}\text { A text description of the meter size(s) covered } \\
\text { by the tariff, e.g " } 5 / 8 \text { ", "less than } 1 \text { ", etc. }\end{array}$ \\
\hline Meternum & Number(single) & 0.625 up to 18 & $\begin{array}{l}\text { A number for the meter size to which the } \\
\text { tariff applies. If it applies to more than one } \\
\text { szie, the largest is entered }\end{array}$ \\
\hline Param1 & $\operatorname{Text}(100)$ & Text & $\begin{array}{l}\text { description of first parameter (other than } \\
\text { meter size) determining which customers are } \\
\text { covered by this tariff. E.g. lot size }=0 \text { to } \\
7000 \text { sq. ft, Temperature Zone }=\text { moderate, } \\
\text { etc. }\end{array}$ \\
\hline Param2 & $\operatorname{Text}(100)$ & Text & $\begin{array}{l}\text { description of second parameter determining } \\
\text { which customers are covered by this tariff }\end{array}$ \\
\hline Addparams & $\operatorname{Text}(100)$ & Text & $\begin{array}{l}\text { description of any additional parameters that } \\
\text { determine which customers are covered by } \\
\text { this tariff }\end{array}$ \\
\hline $\begin{array}{l}\text { Base_begin_mon } \\
\text { th }\end{array}$ & Integer & $1-12$ & $\begin{array}{l}\text { for tariffs based on consumption in a base } \\
\text { period, month base period begins }\end{array}$ \\
\hline Base_begin_day & Integer & $1-31$ & $\begin{array}{l}\text { for tariffs based on consumption in a base } \\
\text { period, day base period begins }\end{array}$ \\
\hline Base_end_month & Integer & $1-12$ & $\begin{array}{l}\text { for tariffs based on consumption in a base } \\
\text { period, month base period ends }\end{array}$ \\
\hline
\end{tabular}


Table A-2 (continued). Fields in the Tariff Table of the Water TAP Database

\begin{tabular}{|c|c|c|c|}
\hline Field Name & Data Type & Field Values & Description and Notes \\
\hline Base_end_day & Integer & $1-31$ & $\begin{array}{l}\text { for tariffs based on consumption in a base } \\
\text { period, day base period ends }\end{array}$ \\
\hline Adjust_month & Integer & $1-12$ & $\begin{array}{l}\text { for tariffs that adjust once a year based on } \\
\text { previous consumption, month adjustment is } \\
\text { done }\end{array}$ \\
\hline Adjust_day & Integer & $1-31$ & $\begin{array}{l}\text { for tariffs that adjust once a year based on } \\
\text { previous consumption, day adjustment is } \\
\text { done }\end{array}$ \\
\hline Last_update & Date/time & Date & $\begin{array}{l}\text { last time the data for this tariff was updated } \\
\text { and/or verified }\end{array}$ \\
\hline Date_entered & Date/time & Date & date when tariff was entered into database \\
\hline $\begin{array}{l}\text { Doc_date_effecti } \\
\text { ve }\end{array}$ & Date/time & Date & $\begin{array}{l}\text { official utility document date tariff goes into } \\
\text { effect }\end{array}$ \\
\hline $\begin{array}{l}\text { Doc_date_expire } \\
\text { d }\end{array}$ & Date/time & Date & official utility document date tariff expires \\
\hline Description & Memo & Text & utility provided description of this tariff \\
\hline Notes & Memo & Text & $\begin{array}{l}\text { comments regarding the tariff model } \\
\text { assumptions or approximations }\end{array}$ \\
\hline
\end{tabular}


Table A-3. Fields in the Component Table of the Water TAP Database

\begin{tabular}{|c|c|c|c|}
\hline Field Name & Data Type & Field Values & Description and Notes \\
\hline Component_id & AutoNumber & $\begin{array}{l}\text { Whole } \\
\text { Numbers }\end{array}$ & Unique identifier for the tariff component \\
\hline Tariff_id & Long Integer & $\begin{array}{l}\text { Whole } \\
\text { Numbers }\end{array}$ & Tariff this component is part of \\
\hline Group_id & Integer & $\begin{array}{l}\text { Whole } \\
\text { Numbers }\end{array}$ & $\begin{array}{l}\text { used to group like components (e.g. fixed } \\
\text { charges with other fixed charges, consecutive } \\
\text { tiers in a block structure) }\end{array}$ \\
\hline Sequence & Integer & $\begin{array}{l}\text { Whole } \\
\text { Numbers }\end{array}$ & identifies the order of a block within a group \\
\hline Rate & Number(single) & Positive number & the rate associate with this component \\
\hline Rate_type & integer & $1-4$ & $\begin{array}{l}1=\text { actual consumption } \$ / \mathrm{HCF}, 2= \\
\text { consumption during a base period }(\$ / \mathrm{HCF}) 3 \\
=\text { fixed }(\$ / \text { billing period) } 4=\text { actual } \\
\text { consumption, } \$ / \mathrm{TG}\end{array}$ \\
\hline Months & $\operatorname{Text}(1)$ & $\mathrm{A}, \mathrm{W}$ or $\mathrm{S}$ & $\mathrm{A}=$ all, $\mathrm{S}=$ Summer, $\mathrm{W}=$ Winter \\
\hline Max & Number(single) & Positive number & $\begin{array}{l}\text { upper limit of consumption range to which } \\
\text { the rate applies. Lower limit is defined by } \\
\text { max of preceding block }\end{array}$ \\
\hline Max_type & Integer & $1-4$ & $\begin{array}{l}1=\text { metered } \mathrm{HCF}, 2=\mathrm{HCF} \text { during a base } \\
\text { period, } 3=\text { percent relative to a base period, } 4 \\
=\text { metered TG }\end{array}$ \\
\hline Altmax & Number(single) & Positive number & $\begin{array}{l}\text { some blocks may have two alternative } \\
\text { maximums -- e.g. } 125 \% \text { of previous } \\
\text { December usage or } 28 \mathrm{HCF} \text {, whichever is } \\
\text { greater }\end{array}$ \\
\hline Altmax_type & Integer & $1-4$ & $\begin{array}{l}1=\text { metered } \mathrm{HCF}, 2=\mathrm{HCF} \text { during a base } \\
\text { period, } 3=\text { percent relative to a base period, } 4 \\
=\text { metered TG }\end{array}$ \\
\hline Logic & Integer & 1 or 2 & $\begin{array}{l}\text { relationship between max and altmax. } 1= \\
\text { "or" } 2=\text { "and" }\end{array}$ \\
\hline Component_name & $\operatorname{Text}(100)$ & Text & component name \\
\hline Group_name & $\operatorname{Text}(50)$ & text & name for this component group \\
\hline
\end{tabular}


Table A-4. Fields in the Utility_Cities Table of the Water TAP Database

\begin{tabular}{|l|l|l|l|}
\hline \multicolumn{1}{|c|}{ Field Name } & \multicolumn{1}{|c|}{ Data Type } & \multicolumn{1}{c|}{ Field Values } & \multicolumn{1}{c|}{ Description and Notes } \\
\hline City_id & AutoNumber & Whole numbers & $\begin{array}{l}\text { unique identifier of this city, county } \\
\text { unincorporated area, or section thereof }\end{array}$ \\
\hline Util_id & Number & Whole numbers & $\begin{array}{l}\text { Identifier of utility which serves this city } \\
\text { or section of a city }\end{array}$ \\
\hline City_name & Text(100) & Text & $\begin{array}{l}\text { Name of the city (or county } \\
\text { unincorporated area) }\end{array}$ \\
\hline Section & Text(50) & Text & $\begin{array}{l}\text { The geographic area of the city ( or } \\
\text { county unincorporated area) covered by } \\
\text { this utility. Could be "all", or "west of } \\
\text { highway 99", for example }\end{array}$ \\
\hline
\end{tabular}

